\title{
NITROGEN FERTILIZATION ON GROWTH AND YIELD RESPONSE OF OAT (Avena sativa $\mathrm{L}$.)
}

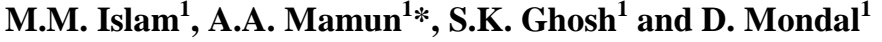 \\ ${ }^{1}$ Agrotechnology Discipline, Khulna University, Khulna-9208, Bangladesh \\ Corresponding E-mail: mamungpbat@ku.ac.bd
}

(Received: 24 September, 2020, Accepted: 04 October, 2020)

Keywords: Oat, $\mathrm{N}$ fertilization, growth, productivity

\begin{abstract}
Nitrogen is one of the main inputs of oat cultivation and its efficient management is a basic for harvesting the maximum potentiality of the crop. An investigation was conducted at field laboratory of Agrotechnology Discipline, Khulna University, Bangladesh to find out the effect of nitrogen fertilizer on growth, yield and yield contributing characters of oat during 2017-2018. The experiment was designed in randomized complete block with seven $\mathrm{N}$ rates $\left(0,30,45,60,75,90\right.$ and $\left.105 \mathrm{~kg} \mathrm{ha}^{-1}\right)$ in triplicate run. Application of $\mathrm{N}$ nitrogen significantly increased the growth and yield of oat. The results showed that $105 \mathrm{~kg} \mathrm{ha}^{-1} \mathrm{~N}$ was supreme in all growth parameters and straw yield but $90 \mathrm{~kg} \mathrm{ha}^{-1} \mathrm{~N}$ was better for main yield parameters and grain yield. The maximum plant height $(101.27 \mathrm{~cm})$, leaf number (11.90), tillers plant ${ }^{-1}$ (9.93), plant density $\left(41.33 \mathrm{~m}^{-2}\right)$ and straw yield $\left(4.70 \mathrm{tha}^{-1}\right)$ were recorded with $105 \mathrm{~kg} \mathrm{ha}^{-1} \mathrm{~N}$ application, whereas the highest grain yield $\left(1.76 \mathrm{t} \mathrm{ha}^{-1}\right)$ was found with $90 \mathrm{~kg} \mathrm{ha}^{-1} \mathrm{~N}$. From the results of the present research, it may be concluded that application of $90 \mathrm{~kg} \mathrm{~N}$ $\mathrm{ha}^{-1}$ could be used for oat production in soils of AEZ 13, Bangladesh.
\end{abstract}

\section{Introduction}

In meeting up human nutrition, the cereals are on the first place in Bangladesh and also in the world. Among the cereals, the oat (Avena sativa $\mathrm{L}$.) is a healthy and useful addition to human diet and animal feed (Barut, 2003; Peterson et al., 2005). Oats are cultivated for the grain, as source of protein, for hay, as winter cover, and are used as a pasture crop in the growing or milk stage during Rabi season. It is adapted to a wide range of soil types, altitude and rainfall conditions. It can tolerate waterlogged conditions better than most of other cereals (Mengistu, 1997). Foods that are prepared with oat include oats bran, oats meal, oats flour and oats flakes, which are mainly consumed as breakfast cereals. Oat straw is used as fodder, but mostly for bedding purposes because of its excellent absorbent qualities. Other food products processed from oat are infant foods, muesli, granola bars, breads and biscuits or cookies. In brewing, oats are mainly used as an ingredient to improve the pleasant flavor properties of the final product. Additionally, new processes have been recently developed to manufacture non-dairy functional products using oats (Duke, 1983).

Oats has traditionally been considered as a low input crop and can be grown on soil with lower fertility. However, it grows poorly without the addition of nutrients. For higher yield, nutrient management is now considered as a great factor when growing oats. The unsatisfactory yield of oats in Bangladesh is mainly ascribed to low soil fertility, inadequate manuring and cultural practices. The agricultural lands of Bangladesh are characterized with low amounts of organic matter having poor ability to retain nutrients. Continuous loss of nutrients from the soil without replacement makes the soil deficient in nutrients or the nutrients reduced to marginal level. The continued depletion of nutrients, particularly $\mathrm{N}$ from soil will eventually reduce soil $\mathrm{N}$ supply and decrease the productivity and quality of the produces. 
High yields of a crop are the result of ensuring environmental, technological, management, capital, and inputs timely. Proper and optimum application of fertilizers not only increases the yield but also favorably affects the quality of the produce (May et al., 2004). Nitrogen is largely responsible for setting up the yield potential of the crop. The use of $\mathrm{N}$ fertilizer is a major factor for the profitable production of most of the crops. The use of optimal $\mathrm{N}$ rates may allow the crop to give higher yield by lixiviating it into available form during crop development. Apart from the other roles played by nitrogen, it is a major constituent of protein and chlorophyll of green plant. However, higher dose of nitrogen cause lodging of crop. Nitrogen deficient plants are stunted, have fewer tillers, smaller heads and finally grain yield is reduced primarily through a reduction in kernels per head and head density. The $\mathrm{N}$ for plant growth is supplied from both the soil and from the application of $\mathrm{N}$ fertilizer. Where the available $\mathrm{N}$ is inadequate for optimum yield and quality, $\mathrm{N}$ fertilizer is required to supply to optimize the production. Soil type, cropping history, yield potential and the season are important factors to consider in $\mathrm{N}$ management decisions (https://www.agric.wa.gov.au).

The main reason for low acreage of oats is that this crop is grown with little care for optimum yield. As a result average yields and gross returns frequently have been low. Many reports of high yields have been made by farmers and researchers, showing that high yields with excellent quality can be attained. Numerous experiments have shown that oats will respond to fertilizer when soil fertility is limiting (Jackson et al., 1994; Koul, 1997; Omer, 1998 and Gasim, 2001). However, several factors are responsible for less than maximum economic return and among them a recommended rate of $\mathrm{N}$ fertilizer is an important factor in determining the potential yield. Nitrogen fertilization is still so complex and is worth to research closely as its effects are very variable due to environmental factors. If an optimum $\mathrm{N}$ fertilizer dose could be marked, then the most profitable rates of $\mathrm{N}$ fertilization could be recommended to the oats producer. In many cases, the producer is also interested to get high straw yield of oats for feeding their animals. However, for the harvest of the increased grain and straw yield it is necessary to apply optimum quantity of $\mathrm{N}$ fertilizer. Considering the importance of $\mathrm{N}$ on the productivity of oats, an investigation was carried out to find out the response of yield and yield components of oat to different doses of $\mathrm{N}$ fertilizer.

\section{Materials and Methods}

Site and soil description: The study to investigate the effect of varying doses of nitrogenous fertilizer on growth and yield of oat was executed at the Professor Dr. Purnendu Gain Field Laboratory of Agrotechnology Discipline, Khulna University, Khulna during Rabi season of 2017-18. The area was located in the agro-ecological zone of Ganges Tidal Floodplain (AEZ 13). The experimental site was situated by latitude $22^{\circ} 79^{\prime} 88^{\prime \prime} \mathrm{E}$, longitude $89^{\circ} 53^{\prime} 44^{\prime \prime} \mathrm{N}$ and elevation of $18 \mathrm{~m}$ above mean sea level with sub-tropical climate. Before sowing the crop, the soil of the experimental field was analyzed in the laboratory for their physico-chemical properties. Soil was well drained, non-saline and non-sodic clay loam type with pH 6.8, total $\mathrm{N} 0.060 \%$, available $\mathrm{P}_{2} \mathrm{O}_{5} 38.0 \mathrm{~kg} \mathrm{ha}^{-1}$ and available $\mathrm{K}_{2} \mathrm{O} 265.0 \mathrm{~kg} \mathrm{ha}^{-1}$.

Treatments and experimental design: The experiment was arranged in randomized complete block design (RCBD) with seven treatments (Table 1) each replicated thrice. A net plot size of $3.0 \mathrm{~m} \times 2.0 \mathrm{~m}$ was maintained for each treatment. A distance of block to block $0.5 \mathrm{~m}$ and that of plot to plot $0.25 \mathrm{~m}$ was maintained. Recommended dose of fertilizers (Eagri, 2012), except N, was applied.

Crop husbandry: Seeds of an Indian oat cultivar Kent, collected from Central Cattle Breeding and Dairy Farm (CCBDF), Dhaka, was used as the planting material in this experiment. Seeds were treated with Vitavax-200 at the rate of $3 \mathrm{~g} \mathrm{~kg}^{-1}$ seed for 24 hours, was sown along the open furrow spaced 25 $\mathrm{cm}$ apart at $4-5 \mathrm{~cm}$ depth at a seed rate of $60 \mathrm{~kg} \mathrm{ha}^{-1}$. Full dose of organic manure (cow dung) was added three weeks before sowing. Recommended full quantity of phosphorus and potash and half dose of nitrogen as per treatment details were applied during final land preparation and thoroughly mixed in 
the soil. Remaining half dose of nitrogen was top dressed after 30 days of seed sowing. The other intercultural operations were kept normal and uniform for all the treatment plots.

Table 1. List of treatments followed in the experiment

\begin{tabular}{clc}
\hline Treatments & Treatment description & Nitrogen rate $\left(\mathbf{k g ~ h a} \mathbf{~}^{-1}\right)$ \\
\hline $\mathrm{T}_{0}$ & No nitrogen (Control) & 0 \\
$\mathrm{~T}_{1}$ & $33.75 \%$ less than recommended & 30 \\
$\mathrm{~T}_{2}$ & $22.5 \%$ less than recommended & 45 \\
$\mathrm{~T}_{3}$ & $11.25 \%$ less than recommended & 60 \\
$\mathrm{~T}_{4}$ & Recommended dose & 75 \\
$\mathrm{~T}_{5}$ & $11.25 \%$ more than recommended & 90 \\
$\mathrm{~T}_{6}$ & $22.5 \%$ more than recommended & 105 \\
\hline
\end{tabular}

Weather information: A summary of the mean fortnightly temperatures, relative humidity, soil temperature and total monthly precipitation is provided in Table 2. Growing season air temperatures were average to below average and precipitation was average to above average during the study period.

Table 2. Fortnightly weather data at the experimental field area during the growing season

\begin{tabular}{cccccccc}
\hline \multirow{2}{*}{$\begin{array}{c}\text { Month \& } \\
\text { fortnight }\end{array}$} & \multicolumn{2}{c}{$\begin{array}{c}\text { Air temperature } \\
\left({ }^{\circ} \mathbf{C}\right)\end{array}$} & \multicolumn{2}{c}{$\begin{array}{c}\text { Relative humidity } \\
(\%)\end{array}$} & $\begin{array}{c}\text { Soil temperature }\left({ }^{\circ} \mathbf{C}\right) \text { at } \\
\text { different soil depths }(\mathbf{c m})\end{array}$ & \multirow{2}{*}{$\begin{array}{c}\text { Rainfall } \\
(\mathbf{m m})\end{array}$} \\
\cline { 2 - 6 } & Max. & Min. & Max. & Min. & $\mathbf{5}$ & $\mathbf{2 0}$ & \\
\hline $\begin{array}{c}\text { November'17 } \\
1\end{array}$ & 31.90 & 19.00 & 98.00 & 50.00 & 19.70 & 24.20 & 19.40 \\
2 & 28.55 & 18.50 & 97.00 & 53.50 & 23.90 & 25.25 & \\
$\begin{array}{c}\text { December'17 } \\
1\end{array}$ & 27.25 & 17.25 & 99.50 & 61.00 & 22.00 & 23.40 & 50.30 \\
2 & 25.70 & 15.15 & 98.50 & 61.00 & 20.55 & 22.55 & \\
January'18 & & & & & & & \\
1 & 22.20 & 10.55 & 97.00 & 50.50 & 17.25 & 19.10 & \multirow{2}{*}{ Nil } \\
2 & 25.30 & 11.50 & 99.50 & 40.50 & 18.35 & 20.20 & \\
February'18 & & & & & & & \\
1 & 28.90 & 16.40 & 96.50 & 39.50 & 21.90 & 22.20 & \\
2 & 31.15 & 18.35 & 97.50 & 40.50 & 23.95 & 24.15 & \\
March'18 & & & & & & & \\
1 & 33.70 & 20.45 & 95.50 & 36.50 & 27.30 & 27.20 & \\
2 & 33.80 & 23.05 & 96.50 & 47.00 & 29.80 & 29.60 & \\
April'18 & & & & & & & \\
1 & 33.70 & 21.70 & 94.50 & 48.50 & 29.10 & 29.70 & \\
2 & 35.20 & 24.55 & 94.00 & 54.00 & 30.35 & 30.60 & \\
\hline
\end{tabular}

*Source: Regional Weather Station, Khulna, Bangladesh

\section{Variables measured}

Ten plants from each plot were selected randomly and data on plant height, leaves plant ${ }^{-1}$, tiller plant ${ }^{-1}$, and numbers of filled and unfilled grains spike ${ }^{-1}$ were recorded. Plant height was measured from the soil level to the highest leaf tip with the help of a meter tape. Three rows from each plot were randomly selected and then numbers of plants were counted from one meter length of each row. Ten randomly selected plants from each plot of each replication were taken into account and numbers of tillers plant ${ }^{-1}$ were counted and their averages were worked out. All the plants of each plot of each replication were harvested and tied into bundles. After threshing and cleaning by winnowing, grain yield and total stover plot $^{-1}$ were measured separately with electric balance and digital scale balance, respectively. The yield was converted on hectare basis in tones. Grain yield was calculated based on a cleaned sample with a moisture level adjusted to $14 \%$. 
Data analysis: The data were analyzed for Analysis of Variance (ANOVA) at an error rate of 5\% to determine the impact of each treatment by using the computer package program STAR (Statistical Tools for Agricultural Research). Construction of graphs, calculation of means and standard errors were carried out by using Microsoft Office Excel 2012 program. The differences among the treatment means were compared by Duncan's New Multiple Range Test (DMRT) at 95\% confidence level. Functional relationships were developed between yield attributes and yield, and between treatments and yield by using simple regression analysis.

\section{Results and Discussion}

\section{Growth attributes}

Plant height is an important morphological character that acts as a potent indicator of availability of growth resources in its vicinity. Different levels of nitrogenous fertilizer had significant effects on plant height of oat at 60 days after sowing (DAS) and at harvest but had no significant effect at 30 DAS (Figure 1). This may be because the uptake of nitrogen by oat plants is low during early development and increased with crop growth. Although only relatively small amounts of fertilizers are required during the very early stages of plant growth, high concentration of nutrients in the roots zone at that time are beneficial in promoting early growth (Hanway, 1966).

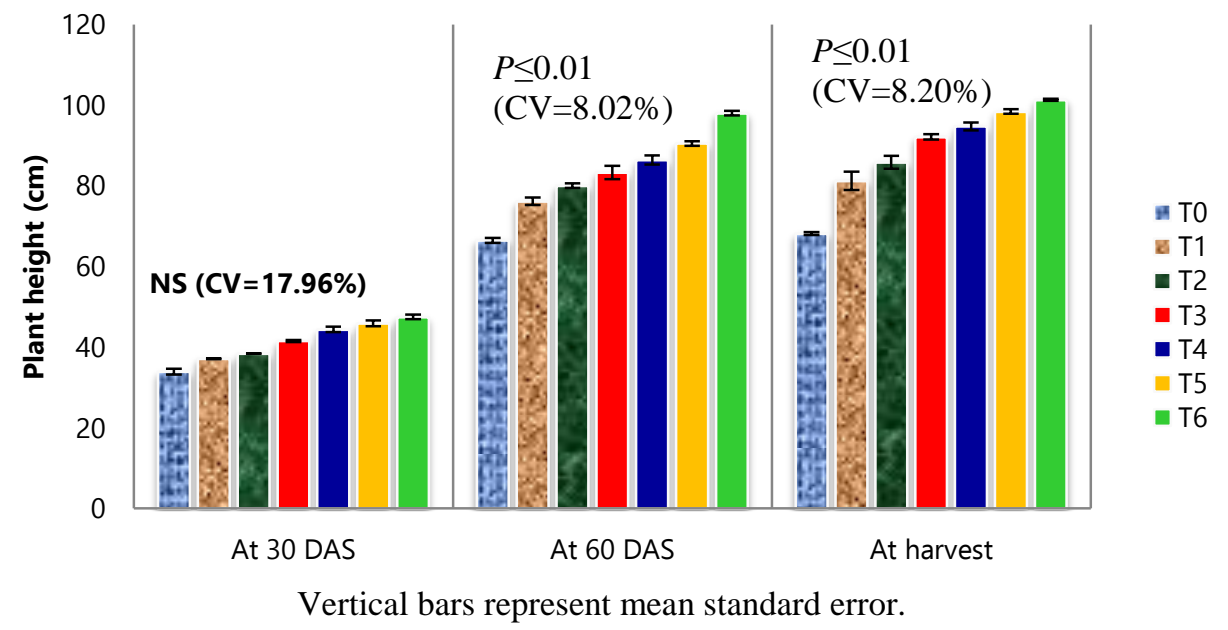

Fig. 1. Effect of different levels of nitrogen on plant height $(\mathrm{cm})$ of oat.

Increasing $\mathrm{N}$ rate resulted a significant increase in plant height. Oats that received the highest $\mathrm{N}$ rate produced taller plants. At 60 DAS as well as at harvest, the highest plant height was observed for $22.5 \%$ more than recommended doses of nitrogenous fertilizer. Throughout the growth period, the minimum plant height was recorded for the plants receiving no additional nitrogen (control). The increase in plant height with nitrogen fertilizer is due to the fact that nitrogen promotes plant growth, increases the number of internodes and length of the internodes which results in progressive increase in plant height (Gasim, 2001). Mangesh (2016) found that application of nitrogen at $100 \mathrm{~kg} \mathrm{ha}^{-1}$ recorded significantly higher plant height as compared to application of $60 \mathrm{~kg} \mathrm{ha}^{-1}$. Maral et al. (2013) found maximum plant height by applying $98 \mathrm{~kg} \mathrm{ha}^{-1}$ nitrogenous fertilizer in oats. These findings are in agreement with this experimental result.

Other growth attributes besides plant height of oats viz., leaves plant ${ }^{-1}$, tillers plant ${ }^{-1}$ and plant density $\left(\mathrm{m}^{-2}\right)$ were recorded at different intervals of crop to analyze the performance and progress of crop growth. All the growth attributes of oats were significantly influenced by different levels of nitrogen 
application (Table 3). Maximum leaves plant ${ }^{-1}$, tillers plant ${ }^{-1}$ and plant density $\left(\mathrm{m}^{-2}\right)$ were obtained with application of $105 \mathrm{~kg} \mathrm{ha}^{-1} \mathrm{~N}$ throughout the growing period. Statistically the maximum number of leaves plant $^{-1}(11.90)$ at harvest was observed when $105 \mathrm{~kg} \mathrm{ha}^{-1} \mathrm{~N}$ was applied followed by the application of $90 \mathrm{~kg} \mathrm{ha}^{-1} \mathrm{~N}$. The minimum number of leaves plant ${ }^{-1}(6.43)$ was recorded in control. The rest of the treatments in respect of the number of leaves plant ${ }^{-1}$ were intermediate. The variation in number of leaves plant ${ }^{-1}$ may be due to the timely availability of $\mathrm{N}$ from applied fertilizer. Statistically the maximum number of tillers plant ${ }^{-1}$ (9.93) was observed when $105 \mathrm{~kg} \mathrm{ha}^{-1} \mathrm{~N}$ was applied followed by $90 \mathrm{~kg} \mathrm{~N} \mathrm{ha}^{-1}$. While the minimum number of tillers 6.87 were observed where no additional $\mathrm{N}$ was applied (control). Fertilizer treatments tended to influence plant density in oats. The statistically significant variation in plant density in oat suggesting that the addition of $\mathrm{N}$ resulted in measurable seedling growth under the conditions of this study. These findings are in line with Godara et al. (2016) who reported that all growth parameters were influenced significantly by increasing levels of nitrogen from 40 to $120 \mathrm{~kg} \mathrm{ha}^{-1}$. Sheoran et al. (2017) revealed that number of tillers $\mathrm{m}^{-1}$ row length were influenced significantly with increasing levels of nitrogen from 40 to $120 \mathrm{~kg} \mathrm{ha}^{-1}$. Anay et al. (2012) revealed that the leaves plant ${ }^{-1}$ and number of tillers plant $^{-1}$ in oats increased significantly with each increment of $40 \mathrm{~kg} \mathrm{~N}$ from $0-100 \mathrm{~kg} \mathrm{ha}^{-1}$.

Table 3. Effect of different levels of nitrogenous fertilizer on growth attributes of oat (Avena sativa L.)

\begin{tabular}{|c|c|c|c|c|c|c|c|c|c|}
\hline \multirow{2}{*}{$\begin{array}{c}\text { Nlevel } \\
\left(\mathrm{kg} \mathrm{ha}^{-1}\right)\end{array}$} & \multicolumn{3}{|c|}{ No. of leaves plant ${ }^{-1}$} & \multicolumn{3}{|c|}{ No. of tillers plant ${ }^{-1}$} & \multicolumn{3}{|c|}{ Plant density $\left(\mathbf{m}^{-2}\right)$} \\
\hline & 30 DAS & 60 DAS & Harvest & 30 DAS & 60 DAS & Harvest & 30 DAS & 60 DAS & Harvest \\
\hline 00 & $4.67 \pm 0.34^{\mathrm{e}}$ & $5.80 \pm 0.07^{\mathrm{e}}$ & $6.43 \pm 0.02^{\mathrm{e}}$ & $6.37 \pm 0.12^{\mathrm{d}}$ & $6.73 \pm 0.10^{\mathrm{e}}$ & $6.87 \pm 0.12^{\mathrm{e}}$ & $28.67 \pm 0.51^{\mathrm{e}}$ & $28.33 \pm 0.51^{\mathrm{f}}$ & $29.33 \pm .51^{\mathrm{e}}$ \\
\hline 30 & $5.00 \pm 0.07^{\mathrm{de}}$ & $6.50 \pm 0.09^{\mathrm{de}}$ & $6.97 \pm 0.12^{\mathrm{de}}$ & $6.67 \pm 0.08^{\mathrm{d}}$ & $7.23 \pm 0.17^{\mathrm{de}}$ & $7.37 \pm 0.14^{\mathrm{de}}$ & $31.00 \pm 0.33^{\mathrm{d}}$ & $31.67 \pm 0.19^{\mathrm{e}}$ & $32.33 \pm 0.19^{\mathrm{d}}$ \\
\hline 45 & $5.47 \pm 0.17^{\mathrm{de}}$ & $7.27 \pm 0.14^{\mathrm{cd}}$ & $7.83 \pm 0.07^{\mathrm{cd}}$ & $7.10 \pm 0.12^{\text {cd }}$ & $7.47 \pm 0.16^{\mathrm{de}}$ & $7.73 \pm 0.17^{\mathrm{d}}$ & $32.00 \pm 0.33^{\mathrm{cd}}$ & $33.33 \pm 0.19^{\text {de }}$ & $33.67 \pm 0.19^{\mathrm{d}}$ \\
\hline 60 & $5.97 \pm 0.27^{\mathrm{cd}}$ & $8.20 \pm 0.29^{\mathrm{c}}$ & $8.73 \pm 0.21^{\mathrm{c}}$ & $7.70 \pm 0.17^{\mathrm{bc}}$ & $8.00 \pm 0.14^{\mathrm{cd}}$ & $8.17 \pm 0.13^{\mathrm{cd}}$ & $33.67 \pm 0.19^{\mathrm{c}}$ & $34.67 \pm 0.19^{\text {cd }}$ & $34.67 \pm 0.19^{\mathrm{cd}}$ \\
\hline 75 & $6.63 \pm 0.28^{\mathrm{bc}}$ & $9.37 \pm 0.28^{\mathrm{b}}$ & $9.97 \pm 0.32^{\mathrm{b}}$ & $8.37 \pm 0.19^{\mathrm{ab}}$ & $8.67 \pm 0.15^{\mathrm{bc}}$ & $8.87 \pm 0.14^{\mathrm{bc}}$ & $35.67 \pm 0.19^{\mathrm{b}}$ & $37.00 \pm 0.33^{\mathrm{bc}}$ & $37.00 \pm 0.33^{\mathrm{bc}}$ \\
\hline 90 & $7.47 \pm 0.32^{\mathrm{ab}}$ & $10.00 \pm 0.31^{\mathrm{b}}$ & $10.73 \pm 0.37^{\mathrm{ab}}$ & $8.70 \pm 0.20^{\mathrm{a}}$ & $9.33 \pm 0.13^{\mathrm{ab}}$ & $9.40 \pm 0.15^{\mathrm{ab}}$ & $37.00 \pm 0.33^{b}$ & $39.00 \pm 0.0^{\mathrm{ab}}$ & $39.33 \pm 0.19^{\mathrm{ab}}$ \\
\hline 105 & $8.13 \pm 0.26^{\mathrm{a}}$ & $11.37 \pm 0.20^{\mathrm{a}}$ & $11.90 \pm 0.23^{\mathrm{a}}$ & $9.10 \pm 0.19^{\mathrm{a}}$ & $9.87 \pm 0.08^{\mathrm{a}}$ & $9.93 \pm 0.09^{\mathrm{a}}$ & $39.33 \pm 0.19^{\mathrm{a}}$ & $40.67 \pm 0.19^{\mathrm{a}}$ & $41.33 \pm 0.19^{\mathrm{a}}$ \\
\hline LS & $* *$ & $* *$ & $* *$ & *** & $* *$ & ** & $* *$ & ** & $* *$ \\
\hline CV (\%) & 5.92 & 4.60 & 4.72 & 4.52 & 3.64 & 3.47 & 1.93 & 2.47 & 2.34 \\
\hline
\end{tabular}

$L S=$ Level of significance, $C V=$ Co-efficient of variation, **= Significant at $1 \%$ level of probability, Means followed by the same letter(s) within columns are not significantly different at $p \leq 0.05$.

\section{Yield attributes}

Yield and all yield contributing characters except harvest index of oat were affected significantly with varying levels of $\mathrm{N}$ (Table 4). Spike length of oat was affected significantly by $\mathrm{N}$ rate. A linear increased in spike length was found with progressively greater $\mathrm{N}$ rates (Table 4). The greater spike length $(38.33 \mathrm{~cm})$ was recorded for the plants supported with $105 \mathrm{~kg} \mathrm{ha}^{-1} \mathrm{~N}$ which was statistically similar with the spike length $(36.00 \mathrm{~cm})$ produced by the plants that received $90 \mathrm{~kg} \mathrm{~N}^{-1}$. The shortest spike $(13.67 \mathrm{~cm})$ was found for the plants under control. This may be due to the fact that low level of nitrogen leads to slow growth and low cell division, thus shortening the length of the spike. Mantai et al. (2016) stated that different levels of nitrogen could significantly increase the panicle length and the panicle weight in oats.

Filled grains spike ${ }^{-1}$ also increased with greater levels of $\mathrm{N}$ indicating that greater filled grains spike ${ }^{-1}$ compensated the cost for increased rate of $\mathrm{N}$ (Table 4) but nitrogen rate had an opposite impact on unfilled grains spike ${ }^{-1}$ and there was a linear decrease in unfilled grains spike ${ }^{-1}$ with an increase in $\mathrm{N}$ rate up to $90 \mathrm{~kg} \mathrm{ha}^{-1}$. The maximum filled grains spike ${ }^{-1}$ (37.80) was found for $90 \mathrm{~kg} \mathrm{~N} \mathrm{ha}^{-1}$ and that of minimum (18.07) for control whereas for unfilled grains spike ${ }^{-1}$, the maximum (12.40) and minimum (6.80) number were recorded for control and $90 \mathrm{~kg} \mathrm{~N} \mathrm{ha}^{-1}$, respectively. 
There was a significant increase in 1000-grain weight resulted by nitrogen levels. Application of 105 $\mathrm{kg} \mathrm{N} \mathrm{ha}^{-1}$ gave the highest $(73.00 \mathrm{~g})$ while the control gave the lowest mean $(54.13 \mathrm{~g})$ seed weight. Increasing the rate of nitrogen application may lead to an improvement in production of photosynthates at source and their transportation to sink efficiency. Mohr et al. (2007) recorded that 1000-grain weight is higher at the rate of $80 \mathrm{~kg} \mathrm{ha}^{-1}$ nitrogen application.

A gradual increase in the application of nitrogen resulted a small but statistically significant increase in grain yield, the summation of all yield components of oats. The highest mean grain yield $\left(1.76 \mathrm{t} \mathrm{ha}^{-1}\right)$ was achieved for $90 \mathrm{~kg} \mathrm{~N}^{-1}$ while the lowest grain yield $\left(0.73 \mathrm{t} \mathrm{ha}^{-1}\right)$ was for control. But the mean grain yield was leveled off at higher $\mathrm{N}$ rate $\left(105 \mathrm{~kg} \mathrm{ha}^{-1}\right)$ although the decrease was very slight. The increasing in nitrogen levels led to increasing of plant height (Figure 1), leaves plant ${ }^{-1}$, tillers palnt ${ }^{-1}$, plant density (Table 3), spike length, filled grains spike ${ }^{-1}$ and 1000-grain weight (Table 4) which led to increasing of grain yield in oat. Nitrogen also plays an important role in increasing the fertility of most florets compared to the low levels (Hanif and Langer, 1972). These findings were corresponded with the results reported by Mantai et al. (2016). Joon et al. (1993) observed that the grain yield of oats increased only up to $80 \mathrm{~kg} \mathrm{~N}^{-1}$ and decreased thereafter with increasing nitrogen. Mohr et al. (2007) showed that low to moderate nitrogen rates significantly increased yield with optimum relative yield achieved with a plant available $\mathrm{N}$ supply of approximately $100 \mathrm{~kg} \mathrm{ha}^{-1}$.

The stover yield of oat was significantly affected by nitrogen application. Application of $105 \mathrm{~kg} \mathrm{~N} \mathrm{ha}{ }^{-1}$ showed significant superiority over that of control. The next best result was found for $90 \mathrm{~kg} \mathrm{ha}^{-1}$. Such a positive yield response may be due to the increase in vegetative production and dry matter accumulation with successive levels of nitrogen application. Increased application of nitrogen, therefore, provides better nutrition to oats which resulted in maximum stover yield. Midha et al. (2015) found that increasing rates of nitrogen application up to $120 \mathrm{~kg} \mathrm{ha}^{-1}$ significantly enhanced the forage yield over the lower doses of nitrogen.

The effect of nitrogen doses on harvest index of oat was not significant. The lowest harvest index $(25.42 \%)$ was calculated for $105 \mathrm{~kg} \mathrm{ha}^{-1}$ nitrogen application but interestingly, the highest value $(30.51 \%)$ was at $30 \mathrm{~kg} \mathrm{~N} \mathrm{ha}^{-1}$ rate. Sharma et al. (2001) revealed that application of $100 \mathrm{~kg} \mathrm{~N} \mathrm{ha}{ }^{-1}$ significantly increased the grain and straw yields and harvest index was significantly reduced by nitrogen fertilization.

Table 4. Effect of different levels of nitrogenous fertilizer on yield and yield attributes of oat (Avena sativa $\mathrm{L}$.)

\begin{tabular}{|c|c|c|c|c|c|c|c|}
\hline $\begin{array}{l}\text { N level } \\
\left(\mathrm{kg} \mathrm{ha}^{-1}\right)\end{array}$ & $\begin{array}{c}\text { Spike length } \\
(\mathrm{cm})\end{array}$ & $\begin{array}{l}\text { No. of filled } \\
\text { grains spike }^{-1}\end{array}$ & $\begin{array}{l}\text { No. of unfilled } \\
\text { grains spike }^{-1}\end{array}$ & $\begin{array}{l}\text { 1000-grain } \\
\text { weight (g) }\end{array}$ & $\begin{array}{l}\text { Grain yield } \\
\left(\mathrm{t} \mathrm{ha}^{-1}\right)\end{array}$ & $\begin{array}{c}\text { Stover yield } \\
\left(\mathrm{t} \mathrm{ha}^{-1}\right)\end{array}$ & $\begin{array}{c}\text { Harvest } \\
\text { index } \\
(\%) \\
\end{array}$ \\
\hline 00 & $13.67 \pm 0.51^{\mathrm{d}}$ & $18.07 \pm 0.37^{\mathrm{e}}$ & $12.40 \pm 0.76^{\mathrm{a}}$ & $54.13 \pm 0.99^{d}$ & $0.73 \pm 0.02^{\mathrm{d}}$ & $1.99 \pm 0.16^{\mathrm{e}}$ & $27.45 \pm 1.89$ \\
\hline 30 & $21.33 \pm 0.51^{\mathrm{c}}$ & $21.67 \pm 0.58^{\mathrm{d}}$ & $9.00 \pm 0.31^{\mathrm{ab}}$ & $56.43 \pm 0.55^{\mathrm{cd}}$ & $1.03 \pm 0.07^{\mathrm{cd}}$ & $2.39 \pm 0.21^{\mathrm{de}}$ & $30.51 \pm 2.39$ \\
\hline 45 & $25.67 \pm 0.83^{c}$ & $25.80 \pm 0.35^{\mathrm{c}}$ & $8.93 \pm 0.49^{\mathrm{ab}}$ & $58.13 \pm 1.00^{\text {bcd }}$ & $1.13 \pm 0.03^{\mathrm{bcd}}$ & $2.99 \pm 0.08^{\mathrm{cd}}$ & $27.49 \pm 0.76$ \\
\hline 60 & $27.00 \pm 0.67^{\mathrm{bc}}$ & $28.53 \pm 0.26^{\mathrm{c}}$ & $8.33 \pm 0.17^{\mathrm{ab}}$ & $61.57 \pm 2.33^{\mathrm{bcd}}$ & $1.34 \pm 0.06^{\mathrm{abc}}$ & $3.56 \pm 0.18^{\mathrm{bc}}$ & $27.59 \pm 1.75$ \\
\hline 75 & $32.33 \pm 0.84^{\mathrm{ab}}$ & $34.00 \pm 0.57^{b}$ & $7.73 \pm 1.00^{\mathrm{ab}}$ & $64.20 \pm 1.79^{\mathrm{abc}}$ & $1.44 \pm 0.08^{\mathrm{abc}}$ & $3.87 \pm 0.20^{\mathrm{abc}}$ & $27.30 \pm 1.88$ \\
\hline 90 & $36.00 \pm 0.67^{\mathrm{a}}$ & $37.80 \pm 0.55^{\mathrm{a}}$ & $6.80 \pm 0.55^{\mathrm{b}}$ & $67.60 \pm 1.95^{\mathrm{ab}}$ & $1.76 \pm 0.14^{\mathrm{a}}$ & $4.32 \pm 0.14^{\mathrm{ab}}$ & $28.82 \pm 1.81$ \\
\hline 105 & $38.33 \pm 0.69^{\mathrm{a}}$ & $35.67 \pm 0.40^{\mathrm{ab}}$ & $7.47 \pm 0.27^{\mathrm{b}}$ & $73.00 \pm 3.23^{\mathrm{a}}$ & $1.61 \pm 0.09^{\mathrm{ab}}$ & $4.70 \pm 0.03^{\mathrm{a}}$ & $25.42 \pm 1.07$ \\
\hline $\mathrm{LS}$ & ** & ** & $*$ & ** & ** & ** & NS \\
\hline $\mathrm{CV}(\%)$ & 7.69 & 3.59 & 19.88 & 5.35 & 13.80 & 9.03 & 12.84 \\
\hline
\end{tabular}

$L S=$ Level of significance, CV= Co-efficient of variation, $* *=$ Significant at $1 \%$ level of probability, * Significant at $5 \%$ level of probability, NS= Not significant, Data followed by same letter $(s)$ are not different statistically.

Although yield varied considerably with the variation in nitrogen rate, reasonably close and positive linear relationships were evident between relative grain yield and panicle length $\left(R^{2}=0.93\right)$, grain yield and filled grains panicle ${ }^{-1}\left(R^{2}=0.91\right)$, grain yield and rate of $\mathrm{N}\left(R^{2}=0.92\right)$ and straw yield and $\mathrm{N}$ rate $\left(R^{2}=0.98\right)$ (Figure 2). Optimum relative grain yield was achieved with plants supplied $90 \mathrm{~kg} \mathrm{~N} \mathrm{ha}{ }^{-1}$ and that of straw yield with $105 \mathrm{~kg} \mathrm{~N}^{-1}$ suggesting that a higher rate of nitrogen was required to optimize yield in oat. The regression analysis revealed that more than $90 \%$ variation in grain yield as 
well as in straw yield could be explained by the variation in nitrogen rate. Previous works were also reported similar results indicating that increased grain yield values due to increased nitrogen rates (Rocquigny et al., 2004; Muurinen et al., 2007).
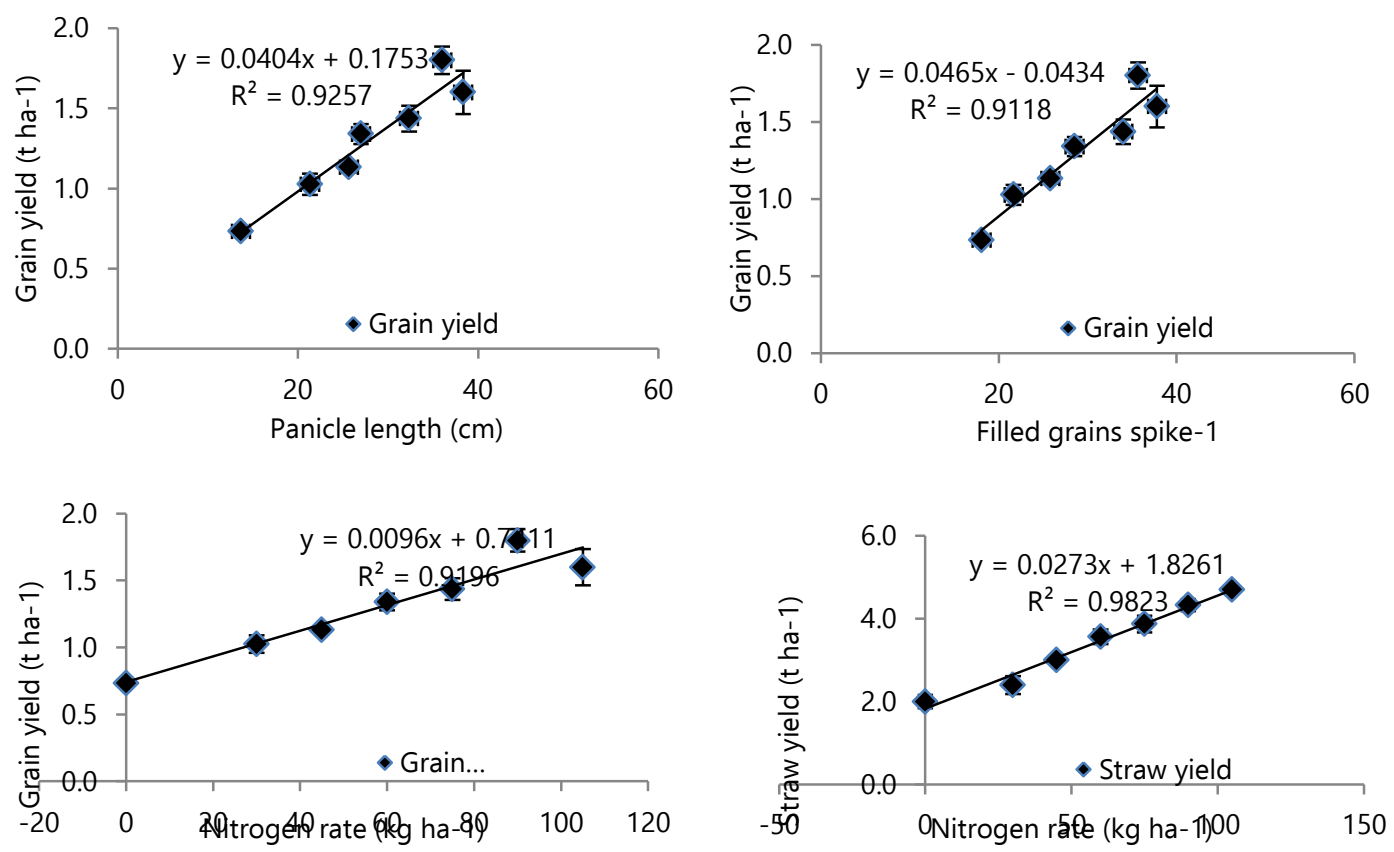

Vertical bars represent mean standard error.

Fig. 2. Functional relationships between yield parameters and grain yield, and between $\mathrm{N}$ levels and yield (grain and straw).

\section{Conclusion}

Yield and yield contributing characters of oat were responsive to increased amount of nitrogen up to $105 \mathrm{~kg} \mathrm{~N} \mathrm{ha}^{-1}$. However, $90 \mathrm{~kg} \mathrm{~N} \mathrm{ha}^{-1}$ was the best for grain yield in oat cultivation in soils of AEZ-13 region.

\section{References}

Anay, R., S.B. Agrawal and P. Naveen. 2012. Effect of soil enrichment in conjunction with bio-organics and chemical fertilizers on yield and quality of fodder oat (Avena sativa L.). J. Trop. For. Sci. 28(3): 59-63. https://www.cabdirect.org/cabdirect/abstract/20143096976

Barut, A.A. 2003. The effect of sowing time and seed size on yield and yield components in some oat types (Avena sativa L.): $\mathrm{PhD}$ thesis//Ankara University, Institute of Natural and Applied Science, Turkey, pp. 114

Duke, J.A. 1983. Handbook of Energy Crops. Purdue University, Center for New Crops \& Plants Products, India.

Eagri. 2012. Oats, rye and triticale - origin, geographic distribution, economic importance, soil and climatic requirement, varieties, cultural practices and yield. http://eagri.org/eagri50/AGRO302/lec05.pdf.

Gasim, S.H. 2001. Effect of nitrogen, phosphorus and seed rate on growth, yield and quality of forage maize (Zea mays L.). M.Sc. Thesis, Faculty of Agriculture, University of Khartoum. 
Godara, A.S., B.S. Satpal and S.K. Duhan. 2016. Effect of different nitrogen levels on forage yield, quality and economics of oat (Avena sativa L.) genotypes. Forage Res. 41(4): 233-236.

Hanif, M. and R.H.M. Langer. 1972. The vascular system of the spike let in wheat (Triticum aestivum). Ann. Bot. 36(4): 721-727.

Hanway, J.J. 1966. How a corn plant develops. Special Report No. 38, Iowa State University of Science and Technology, Cooperative Extension Service.

https://www.agric.wa.gov.au/. Accessed on: 27.12.2019.

Jackson, G.D., R.K. Berg, G.D. Kushnak, T.K. Blake and G.I. Yarrow. 1994. Nitrogen effects on yield, betaglucan content, and other quality factors of oat and waxy hulless barley. Commun. Soil Sci. Plant Anal. 25(17-18): 3047-3055.

Joon, R.K., B.D. Yadav and A.S. Faroda. 1993. Effect of nitrogen and cutting management on grain production of multi-cut oat (Avena sativa). Indian J. Agron. 38(1): 19-21.

Koul, G.G. 1997. Effect of sowing methods, nitrogen levels and seed rates on yield and quality of fodder maize (Zea mays L.). M.Sc. Thesis, Faculty of Agriculture, University of Khartoum.

Mangesh, S.S. 2016. Effect of different levels of nitrogen on performance of fodder oat (Avena sativa L.) varieties under lateritic soil of Konkan region. M.Sc. Thesis, Dr. Balasahed Sawant Konkan Krishi Vidyapeeth, Dapoli (Agricultural University), Ratnagiri (Maharashtra), India.

Mantai, R.D., J.A. Gonzalez de Siva, E. Gh. Arenhardt, O.B. Scremin, A.T. Woschinski de Mamann, R.Z. Frantz, A.C. Valdiero, R. Pretto and D.K. Krysczun. 2016. Simulation of oat grain (Avena sativa) using its panicle components and nitrogen fertilizer. Afr. J. Agric. Res. 11(40): 3975- 3983. DOI: 10.5897/AJAR2016.10943

Maral, H., Z. Dumlupinar, T. Dokuyucu and A. Akkaya. 2013. Response of six oat (Avena sativa L.) cultivars to nitrogen fertilization for agronomical traits. Turkish J. Field Crop. 18(2): 254-259.

May, E.W., R.M. Mohr, G.P. Lafond, A.M. Johnston and F.C. Stevenson. 2004. Effect of nitrogen, seeding date and cultivar on oat quality and yield in the Eastern Canadian Prairies. Can. J. Plant Sci. 84(4): 1025-1036.

Mengistu, A. 1997. Conservation-based forage development for Ethiopia. Self Help Development International, Addis Ababa, Ethiopia. p.170.

Midha, L.K., B.S. Duhan and S.K.M. Arya. 2015. Performance of promising entries of oat (Avena sativa L.) under different nitrogen levels. Forage Res. 41(2): 122-125.

Mohr, R.M., C.A. Grant, W.E. May, and F.C. Stevenson. 2007. The influence of nitrogen, phosphorus and potash fertilizer application on oat yield and quality. Can. J. Soil Sci. 87(4): 459-468.

Muurinen, S., J. Kleemola and P. Peltonen-Sainio. 2007. Accumulation and translocation of nitrogen in spring cereal cultivars differing in nitrogen use efficiency. Agron. J. 99(2): 441-449. DOI: 10.2134/agronj2006.0107

Omer, E.A. 1998. Farm yard manure and urea fertilization on growth and forage yield of two maize (Zea mays L.) cultivars. M. Sc. Thesis, Faculty of Agriculture, University of Khartoum.

Peterson, D.M., D.M. Wesenberg, D.E. Burrup and C.A. Erickson. 2005. Relationships among agronomic traits and grain composition in oat genotypes grown in different environments. Crop Sci. 45(4): 1249-1255. DOI: $10.2135 /$ cropsci2004.0063

Rocquigny, P.J., M.H. Entz, R.M. Gentile and S.C. Duguid. 2004. Yield physiology of a semi dwarf and tall oat cultivar. Crop Sci. 44(6): 2116-2122. DOI: 10.2135/cropsci2004.2116

Sharma, M.S., B.P. Singh and S.D. Mishra. 2001. Influence of cutting schedules, nitrogen and phosphorus levels on growth and yield of oat. Range Manag. Agrofor. 22(1): 60-64.

Sheoran, R.S., U.N. Satpal Joshi, B.S. Duhan, P. Kumari, S. Arya and D.S. Phogat. 2017. Agronomic evaluation of oat (Avena sativa L.) genotypes for forage yield, quality and economics under varying levels of nitrogen. Forage Res. 43(1): 35-38. 